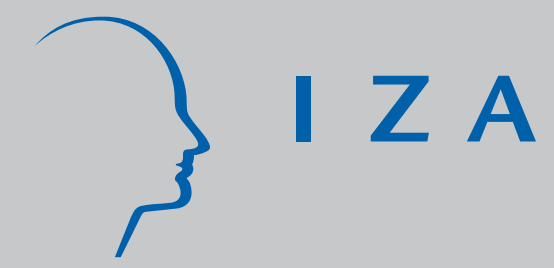

IZA DP No. 491

On the Production of Victory: Empirical Determinants of Battlefield Success in Modern War

Ralph Rotte

Christoph M. Schmidt

May 2002 


\title{
On the Production of Victory: Empirical Determinants of Battlefield Success in Modern War
}

\author{
Ralph Rotte \\ RWTH Aachen, CEPR London and IZA, Bonn \\ Christoph M. Schmidt \\ University of Heidelberg, CEPR London and IZA, Bonn
}

Discussion Paper No. 491
May 2002

IZA

P.O. Box 7240

D-53072 Bonn

Germany

Tel.: +49-228-3894-0

Fax: +49-228-3894-210

Email: iza@iza.org

This Discussion Paper is issued within the framework of IZA's research area The Future of Labor. Any opinions expressed here are those of the author(s) and not those of the institute. Research disseminated by IZA may include views on policy, but the institute itself takes no institutional policy positions.

The Institute for the Study of Labor (IZA) in Bonn is a local and virtual international research center and a place of communication between science, politics and business. IZA is an independent, nonprofit limited liability company (Gesellschaft mit beschränkter Haftung) supported by the Deutsche Post AG. The center is associated with the University of Bonn and offers a stimulating research environment through its research networks, research support, and visitors and doctoral programs. IZA engages in (i) original and internationally competitive research in all fields of labor economics, (ii) development of policy concepts, and (iii) dissemination of research results and concepts to the interested public. The current research program deals with (1) mobility and flexibility of labor, (2) internationalization of labor markets, (3) welfare state and labor markets, (4) labor markets in transition countries, (5) the future of labor, (6) evaluation of labor market policies and projects and (7) general labor economics.

IZA Discussion Papers often represent preliminary work and are circulated to encourage discussion. Citation of such a paper should account for its provisional character. A revised version may be available on the IZA website (www.iza.org) or directly from the author. 


\section{ABSTRACT}

\section{On the Production of Victory: Empirical Determinants of Battlefield Success in Modern War*}

Using a data set of historical battles from 1600 to 1973, this paper analyzes the empirical determinants of tactical success in modern war. Based on a reduced form approach we consider key elements of military theory as factors in the production of combat success, formalized in a military production function. The paper focuses on the relationship of material and non-material factors to battlefield success, and especially on the role of superior force strengths. Contrary to the emphasis on technology which can be found in the recent literature, our estimation results indicate that numerical superiority has retained its crucial role for battlefield performance throughout history. In general, human elements of warfare, like leadership, morale and surprise, have continued to be important determinants of battle outcome despite technological progress in weapons.

JEL Classification: C25, D29, H56, N40, O39

Keywords: battlefield success, numerical superiority, leadership, technical progress, military technology, military production function

Ralph Rotte

Institute for Political Science

RWTH Aachen

Ahornsr. 55

52074 Aachen

Tel.: +492418024824

Fax: +492418022162

Email: rotte@ipw.rwth-aachen.de

\footnotetext{
* We would like to thank Thomas K. Bauer, Martin Biewen, Jurgen M. Brauer, Timothy Guinnane, Allan C. Stam and Hew Strachan for very valuable comments on this paper, Albrecht Bläsi for his competent research assistance, and Robert L. Helmbold for providing the data used. Financial support by the German Science Foundation (DFG) is gratefully acknowledged.

First draft: December 1999; this revision: April 2002.
} 


\section{Introduction}

Based on technological developments in military affairs in the past, which fundamentally changed doctrinal and organizational traditions in modern warfare, this paper investigates the empirical consequences of changed technological environments for the determinants of battlefield success from the early seventeenth to the late twentieth century. Following seminal contributions in military history about the technology-war connection, e.g. by Howard (1976), Headrick (1981), McNeill (1982), Parker (1988), O'Connell (1989), and van Creveld (1989), it addresses the general literature about the tactical and operational consequences of technological change in history. It focuses in particular on the importance of human qualities in combat when technological change, e.g. ever-increasing firepower, seems to decrease man's role relative to the machine, degrading him to another element of military material.

Such a perspective, which finds support by the experience of industrialized mass sacrifice in the two world wars, clearly contrasts with a military professional view of modern combat which would emphasize the role of man as a highly-skilled operator of more and more sophisticated weapon systems, facing the ever-growing complexity of warfare. Thus, in brief, the paper tries to provide empirical insight into the issue which human elements, like morale, leadership and training persist in a combat environment that is more and more shaped by modern technology. In this sense, the paper is a contribution to a historical perspective of defense and peace economics in its evolution as an interdisciplinary field of research (Hacker, 1994).

The paper is organized as follows: Section 2 outlines our approach interpreting battle success as an outcome of a military "production function", with technological, human and other factors as inputs. In section 3, seven main periods of military technological development are identified, which are covered by the available data (1600-1973). Section 4 describes the data set provided by the US Army Concepts Analysis Agency (Helmbold, 1991) and discusses some theoretical expectations to be tested by the empirical approach. Section 5 explains this approach, introducing briefly the standard statistical models and specifications used in the derivation of the empirical results. Section 6 gives an interpretation of the results and provides simulation results for the historical battles of Waterloo and Gettysburg. Section 7 concludes and hints at some remaining open questions. 


\section{A stylized production function approach to combat}

In this analysis, we treat the outcome of battlefield encounters as the result of a military "production function". Looking at the classical and modern literature on warfare and its key concepts of success, this perspective seems rather natural from an economist's point of view. Clausewitz (1990) or Dupuy (1987; 1990), for example, have identified basic theoretical aspects of military success or failure throughout history, e.g. superiority in numbers, morale, surprise, and supply (logistics). These elements are typically interpreted as initially given conditions which come to bear in the process of fighting a battle, and which ultimately lead to its outcome, i.e. victory, defeat or draw (throughout the manuscript, success is measured from the perspective of the attacker).

Such a view is obviously similar to the ordinary production function approach in microeconomics which identifies inputs $x_{1}, x_{2}, \ldots, x_{n}$ whose interaction within a technology $f$ results in fabrication of some good $y^{*}$. Think of this good $y^{*}$ as the outcome of a battle, measuring on a metric scale not only the direction (victory yes/no captured by positive and negative values of $y^{*}$, respectively), but also the extent of the outcome (a close victory implying a modest positive value of $y^{*}$, an overwhelming defeat large - in absolute value - negative realizations of $y^{*}$ etc.). Furthermore, given that military theory and history provide us with the $n$ input factors of tactical and operational success in war we could define a "production function" of battlefield performance as

$$
y^{*}=f\left(x_{1}, \ldots, x_{n}\right),
$$

where $y^{*}$ is again the latent variable representing victory or defeat. Moreover, by introducing an error variable $\varepsilon$ we receive a probabilistic approach to military success which resembles Clausewitz" notion that war is too complex a phenomenon to be explained (and waged) by deterministic formulas,

$$
y_{j}^{*}=f\left(x_{l j}, \ldots, x_{n j}\right)+\varepsilon_{j} ; \quad j=1, \ldots, m,
$$

with $m$ denoting the number of battles observed in the data set.

Obviously, this equation could be estimated by an ordinary linear or non-linear regression approach (depending on $f$ ) if we could indeed observe the propensity for victory or defeat, $y^{*}$, directly. A general and usual assumption for $f$ would then be e.g. a Cobb-Douglas production function which could be estimated by OLS in a log-linear regression model. The latent nature of the endogenous variable precludes such an approach. Typically, we do observe 
either a binary indicator of battle success $y_{j}$ (victory yes/no) or an ordered categorical variable measuring battle performance, necessitating a non-linear approach to estimation. Specifically, for the latent variable we postulate a simple linear-additive production function

$$
y_{j}^{*}=\beta_{0}+\beta_{1} x_{1 j}+\beta_{2} x_{2 j}+\ldots+\beta_{n} x_{n j}+\varepsilon_{j}=\beta^{\prime} x_{j}+\varepsilon_{j},
$$

where almost all exogenous variables are discrete indicators of relative military capabilities of the fighting parties. The observed battle success $y$ is linked to the latent propensity $y^{*}$ by an observation rule

$$
y_{j}= \begin{cases}1 & \text { if } y^{*}>0 \\ 0 & \text { otherwise. }\end{cases}
$$

Admittedly, this production technology based on a simple linear combination of the $x_{i}$ is rather restrictive, since it assumes linear isoquants and thus implies perfect substitutability among the various production factors. Nevertheless, given the structure of our data, this approach seems adequate for our basic question if and how much material, i.e. mainly technological and quantitative, factors have overcome non-material, i.e. mainly human, elements of warfare in history. Specifically, our analysis addresses whether the production technology experienced qualitatively remarkable changes over time.

\section{The development of military technology}

Historical changes in military technology

Van Creveld's (1989) and Keegan's (1994) seminal works suggest that there have been three fundamental changes in military history: the change from muscle-bound to industrialized warfare, or from van Creveld's "age of tools" to the "age of machines" after 1500 A.D., culminating in Napoleonic mass armies and starting the trend of substituting firepower for manpower; the change to the "age of systems" with the integration of technology into complex networks, culminating in the Blitzkrieg experience of the Second World War; and the change to the "age of automation" after 1945, characterized by the vast increase in information needed to run military forces, and thus the computerization of warfare.

These are the most basic technology-driven changes in warfare. This article, however, is concerned with the impact of technological change on the tactical and operational level, i.e. with the question whether technological change actually altered the determinants of battlefield 
success. For while technology enthusiasts tend to neglect the role of numbers and human factors like morale in favor of technological superiority and, possibly (at most), training, sceptics hint at the persistent importance of tactical and psychological factors in combat. The basic problem is thus the relative relevance of quantitative and qualitative, as well as of material and nonmaterial elements for the effectiveness of armed forces. The ultimate proof of an army's fighting abilities and effectiveness, however, is victory on the ground.

The strategic and political determinants of success in war have already been empirically investigated by Stam (1996). In exploring the connection between democracy and battlefield performance, Reiter and Stam (1998) have found that democratic armies had significant advantages in logistics, initiative and leadership in the period from 1800 to 1982 . Winning battles is certainly not the same as winning wars, although there is some correlation. If we are interested in the factors directly influencing casualties or the outcome of actual fighting, however, we have to turn to the tactical and operational level (Dupuy, 1987). Therefore, in this analysis we explore the determinants of battlefield success in a changing technological environment in modern history.

Basically, one may distinguish three possibilities for fundamental technological change in warfare: progress in firepower, i.e. in the range, precision, firing frequency, and caliber or impact of firearms; progress in mobility, i.e. in the range and speed of forces; and progress in $\mathrm{C}^{3} \mathrm{I}$ technology, i.e. in the availability and processing capabilities of information and communication. A more detailed look at the era of modern warfare since about 1600 provides us with several basic changes in warfare which were mainly driven by technological innovation. Combining the assessment of technological change in warfare provided by Stegemann (1940), Montgomery (1968), Dinter (1985), Dupuy (1990), Dupuy and Dupuy (1993), Messenger (1995), Parker (1995a; 1995c), van Creveld (1997a; 1997b) and Townshend (1997) gives us seven basic periods of prevalent combat technology with major consequences for tactical doctrine, organization etc.

Based on the three interacting fields of fundamental technological change in war these periods are: (1) the 17th century, (2) most of the 18th century until about 1780, (3) the late 18th and first half of the 19th century, (4) the transformation phase until about 1890, (5) the highperiod of infantry and artillery, First World War-style, between about 1890 and 1930, (6) the 
period of increased mobility, Second World War-style, between about 1930 and 1960, and (7) the advent of the current electronically managed warfare, between the mid-1960s and the 1970s.

\section{Seven periods of military technology, 1600-1973}

Dupuy (1990) and Dupuy and Dupuy (1993) give an overview of the basic technological developments and changes in warfare since the beginning of the 17th century. Between 1600 and 1700 the technology of war was characterized by the matchlock musket, the pike and the plug bayonet for the infantry, and by the reduction in weight and the standardization of calibers of artillery guns, introduced by Gustavus Adolphus. Gunpowder was standardized and infantry tactics were based on a mixture of musketeers firing volleys and pikemen following a modern kind of phalanx tactics, as in the Thirty Years War, 1618-1648 (Lynn, 1995a; Parker, 1995b; Childs, 1997). Increasing firepower, following the introduction of the flintlock musket, the double-ended iron ramrod, lighter guns and howitzers with smaller calibers as well as the socket bayonet, led to the elimination of the pike from the battlefield and to linear tactics and operational manoeuver doctrine. Rigid discipline and training resulted in higher mobility of units on the battlefield. Exemplary wars of this period include the War of the Spanish Succession, 1701-1714, the Great Northern War , 1700-1721, and the wars of Frederick the Great, 1740-1763 (Lynn, 1995a; Black, 1997).

From the end of the 18th century until approximately the mid-1800s, light infantry with rifles as well as modern artillery reformed according to the Gribeauval system (adopted from the 1770s) with standardized guns and howitzers, lighter pieces and improved carriages, led to lines of infantry thinning to just two or three ranks. The divisional and corps systems were introduced, embracing all three arms, infantry, cavalry and artillery. Following the levée en masse, tirailleur tactics and massed columns became two standard elements of mobile infantry combat, as in the Wars of the French Revolution, 1792-1800, and in the Napoleonic Wars, 1800-1815 (Lynn, 1995b; Black, 1997; Forrest, 1997).

Between about 1850 and 1890, muzzle-loading rifles, Minié bullets and percussion caps substituted for the smoothbore muskets and flintlocks, and were quickly improved by breech loading mechanisms. Similarly, artillery firepower increased with the introduction of the Congreve light gun, breech loading artillery pieces and of shells and shrapnels instead of solid shot, grape or canister. While the fundamental changes were mainly based on increasing 
firepower, the military revolution of the second half of the 19th century were also characterized by radical improvements in mobility and $\mathrm{C}^{3} \mathrm{I}$ capabilities, due to the introduction of railways and field telegraphs. Exemplary wars of this period include the Crimean War, 1853-1856, the war of Napoleon III against Austria, 1859, the wars of German unification, 1864-1871, and the American Civil War, 1861-1865 (Murray, 1995a; French 1997).

The trends demonstrated in these wars were massively accelerated during the last years of the century, which led to the period before and after the Great War, 1914-1918 (with the Boer War, 1899-1902, the Russo-Japanese War, 1904/5 and the Balkan Wars, 1912/13, as additional examples), being characterized by innovations like the machine gun, magazine rifles, airplanes and airships, smokeless powder, the field telephone, recoil mechanisms for artillery, barbed wire, and poison gas (Stegemann, 1992; Murray, 1995b; Murray, 1995c; Murray, 1995d; Bourne, 1997). The core of military tactics gradually shifted down to the infantry battalion, company and team levels as well as to massive artillery concentration against more and more complex entrenchments (Andrews, 1977; Dupuy, 1990: 225ff.). The infantry line as well as cavalry in general disappeared from modern battlefields.

The period between 1930 and 1960 was then determined by technologies utilized in the Second World War, 1939-1945, like tanks, tactical and strategic aircraft made of aluminum, rocket weapons, bazookas, radar, radio communications, transport by truck, and self-propelled artillery. Other important wars of this period were also the Spanish Civil War, 1936-1939, and the Korean War, 1950-1953 (Murray, 1995d; Murray, 1995e; Murray, 1995f; Overy, 1997). Finally, the introduction and utilization of (combat) helicopters, satellite and long range air reconnaissance, rocket missiles and guided missiles were characteristics of the seventh period, with the Vietnam War, 1965-1973, and the Yom Kippur War, 1973, as the most striking examples (Murray, 1995f; Towle, 1997).

Of course, military technology, tactics, and organization were not static within those periods. The 17th century, for example, saw a constant adaption of the standard formation of the "Spanish Square" of pikemen and musketeers with priorities shifting from the former to the latter (Dupuy and Dupuy, 1993: 575ff.). Therefore tactical and technological change occur in a permanent fashion throughout time. In this process, the impact of technological transitions depend on the implementation, not mere existence of new technologies. Nevertheless, in principle, the selected periods can be clearly distinguished from each other either by rapid 
military change, like the European military reforms initiated by Louis XIV in the late 17th century, the French Revolution at the end of the 18th century, and the introduction of modern tank and of air warfare in the 1930s, or by relatively long periods of relative peace during which the next major wars were prepared, as in the mid-1870s until the mid-1890s, or in the 1920s and early 1930 s.

\section{Data set and major hypotheses regarding the production of victory}

\section{Previous research and data}

The empirical determinants of success as well as of casualties in modern combat have been the topic of detailed research by military agencies and military scientists. Benchmark contributions have been made by Dupuy's $(1979 ; 1987 ; 1995)$ Quantified Judgement (QJM) and Tactical Numerical Deterministic (TNDM) Models, or Helmbold's (1997) statistical modeling of battles and engagements. Basically, the QJM approach builds on a quantitative assessment of weapons effects, of tactical formations, and the opponents' relative quantitative and qualitative standings, which are mainly deduced from engineering tests or field exercises, and connected by more or less empirically founded formulas. Inserting the data on the historical circumstances of battles then allows to predict outcomes and casualties, and to compare predicted and actual results. Helmbold (1997) applies nonparametric statistical techniques in order to fit historical data and identify the driving factors of battle success. Based on this literature, this analysis uses standard parametric models from econometrics in order to estimate the empirical determinants of battle success.

The data set we use has been provided by Helmbold (1991) and is constructed in a fashion similar to the data used in the QJM or TNDM. It consists of information for about 660 historical battles and engagements between 1600 and 1982. Eliminating battles with too many missing variables leaves us with a set of 625 observations for a period from 1600 to 1973 . All seven periods distinguished above are covered well by our data (1600-1700: 48, 1701-1779: 42, 1780-1849: 74, 1850-1889: 69, 1890-1929: 145, 1930-1960: 194, 1961-1973: 53). The construction of the data set makes it especially relevant from the tactical and operational point of view, since it splits longer battles into a number of distinct clashes which enable us to distinguish exactly attacking and defending side (Bauer and Rotte, 1997). For example, the battles of the Marne in September 1914 and of Kursk in July 1943 are split into 8 and 7 separate 
operations, respectively. Cross-case correlation of errors is mitigated by restricting the perspective to the relative position of the attacking side.

In principle, the data set provides information about quantitative and qualitative aspects of the armies facing each other, like personnel strengths and numbers of artillery tubes, tanks, and close air support sorties. Except for personnel strengths, however, there are many missing variables, especially for variables on heavy equipment (artillery, tanks) and support systems (planes). This is of course partly due to their non-existence in the relevant subperiods, and partly due to missing information. We therefore rely only on the force strengths involved in the battles as quantitative measures of the actual numbers of men and material in combat. Experts' discrete assessments of qualitative factors include the attacker's relative advantage in air superiority, morale, technology, logistics, intelligence, leadership, etc.

One fundamental methodological problem of the data set is obviously that the data are all based on ex-post judgements. The military historians of course knew the outcome of the battles when they made the codings. Nevertheless, we proceed under the maintained assumption that the data set is suitable for our empirical questions. Assessments of the qualitative aspects of historical events always have the problem of hindsight which can only be overcome in principle by assuming professional, scientific judgement by the experts involved. Due to the number of observations and variables in our data set, our empirical approach seems at least superior to any anecdotal evidence usually given in the military history literature.

Table 1 gives an overview of the variables and their definitions. The binary variable we use as the principal dependent variable in our empirical investigations, victory, is constructed from the data set's information about the outcomes of the battles included (win, lose or draw). Following Clausewitz's discussion of the defense as the stronger form of war, which only needs to hold to be successful, while the attacker has to dispose of the status quo in order to win actually (Clausewitz, 1990: 360ff.), we define the small number of drawn battles in the data set as defeats of the attacker. On the average, 3 out of 5 battles were won by the attacking side, although there have been intertemporal changes (not documented in Table 1), characterized by relatively high success rates in the first (1600-1700) and the two last periods (1930-1973), and relatively low success rates in the fourth period (1850-1889).

Our principal determinant of interest, the force ratio, has averaged approximately 2 over the course of history, with a clear tendency to rise over time (also not documented in Table 1). 
For the historical battles covered by the data set, it ranges from one fourth to almost 17 . Qualitative variables capturing human elements of combat are indicator (1/0) variables, taking the value of unity if the attacker had an advantage in leadership (this was the case in approximately 1 out of 4 battles), training (somewhat less than 1 out of 5 battles), or morale (slightly more than 1 out of 5 battles). On the other hand, qualitative variables assessing an attacker's technological advantage are the indicator (1/0) variables logistics (nearly 1 out of 10), intelligence (slightly more than 1 out of 10), and technology (unity only in very few battles). Finally, two indicator (1/0) variables tie down specifics of the battle situation, defensive posture (giving an advantage to the defender in nearly 1 out of 5 battles) and surprise (with surprise being on the side of the attacker in slightly more than 1 out of 4 battles).

\section{Relative combat effectiveness}

While these variables can be interpreted straightforwardly, one additional qualitative variable which is available in the original data set is of special interest. In Dupuy's original deterministic model, a variable relative combat effectiveness was intended to cover the effects of all intangible behavioral and unidentified operational variables of combat (Dupuy, 1995: 105ff.). Most of the relevant variables have been measured separately in our data set, and have been classified according to the $0 / 1$ pattern described in Table 1. In Dupuy's model, relative combat effectiveness was calculated as the ratio of the actual battle outcome and the theoretical combat power of the opponents. Battle outcome was based on the ratio of result values for each side, constructed from the assessed degree of mission accomplishment, spatial effectiveness (i.e. gains or losses of ground) and casualty effectiveness, while combat power was the pre-battle ratio of army strengths weighted according to the operational circumstances of battle. Thus, as a continuous variable, combat effectiveness gave the quality-corrected number of side A's soldiers equivalent to one soldier of side B (Dupuy, 1995: 162ff.), thereby confounding outcome and its determinants.

Unsurprisingly, empirical investigation showed a close correspondence between (the square of) the combat effectiveness value and the ratio of casualty-inflicting rates of the opposing sides in battle, i.e. the ratio of casualties inflicted on side A per man of side B and casualties inflicted on side B per man of side A (Dupuy, 1990: 163f.). We purposely do not include this variable in our analysis, since by construction combat effectiveness is an 
endogenous variable. Nevertheless, sensitivity analysis by looking at the effect of including the variable into our estimations reveals that this endogeneity problem would not affect our results substantially: Estimations with combat effectiveness as an additional regressor did not result in substantial changes in the empirical results.

\section{Some expectations}

Using these observations, we investigate the empirical determinants of an attacker's success in combat between the early 17 th and the late 20 th century. The vast literature on military history leads us a to a number of expectations on how the variables should affect the outcome of battles. Following Lanchester's (1977) seminal theoretical work, we expect a significantly positive, but decreasing effect for the numerical superiority of the attacking side. Lanchester's classical square law as illustrated by Dinter (1985: 115ff.), for example, and adapted by Dupuy (1979; 1987) argues that, everything else being equal, relative combat power is not increasing linearly in the simple ratio of force strengths, but rather in its square. Another aspect of nonlinearity is diminishing returns on superior effectiveness in combat. That is, with rising relative strength in forces, further increases in quantitative as well as qualitative superiority will yield lower additional returns to the likelihood of winning a battle.

On the other hand, with improving technology, one could expect a decline in the importance of numerical superiority due to a general substitution of technology and firepower for numbers. Given the experience of the failure of massed infantry attacks against machine guns and artillery positions in the world wars, for instance, we thus expect a stepwise decline in the role of numerical superiority throughout the periods of warfare analyzed. Correspondingly, we expect an increase in the (positive) impact of technological superiority on the likelihood of winning. Admittedly, relative technological superiority may have been extraordinarily effective already in the past, as for example the breech-loading Prussian Dreyse gun in the battle of Königgrätz against the Austrians, who were still equipped with smooth-bore muskets in 1866. Nevertheless, since technological progress in warfare is ever-accelerating, and therefore quality jumps in weapons concerning for example fire frequency and precision, become more and more impressive in time, we expect some change between the periods selected. Since the effective use of modern equipment largely depends on the supply of ammunitions, fuel and spare parts as well 
as on information about enemy movements, target locations, etc., we expect a similar effect for logistics and intelligence.

Due to the automation of modern warfare, one could imagine that there should have been some decline in the importance of better morale in combat. The background to such a view is the image suggested by military history of a progression towards cold, impersonal, technical combat between machine-like men relying on ever-increasing firepower. On the other hand, elements of modern combat like the "emptiness of the battlefield", and the need to rely on relatively smaller units might result in a higher need for better morale substituting for direct control and enforced discipline of the troops. Since the simple availability of modern technology does not per se lead to improved chances in battle, we expect a persistent positive role for leadership throughout history. After all, it is this variable which provides the congruence of weapons, tactics and doctrine (Dupuy, 1987: 213ff.) as well as the organizational superiority in handling modern arms, which seem essential for success in combat in general.

One should also expect an increasingly positive role for training due to the growing complexity of modern arms whose effective use requires intensive practice. On the other hand, however, technological progress might also mean easier use, e.g. if one compares the loading and firing procedure of a matchlock musket to a modern rifle. Ultimately, more "brilliant" systems might need less training (Metz, 1997). Moreover, the progress in arms sophistication has been accompanied by an increasing erosion of traditional boundaries between the civilian and the military realms (Bacevich, 1997). Civilian capabilities have become more and more useful for combat as a consequence of the generally increasing qualifications of recruits and improved transferability of basic technological as well as organizational skills. A historical example for this development is provided by the Boer War (1899-1902) where less trained but more flexible British reservists proved more useful for modern war than the regular soldiers (de Bloch, 1901: 830f.).

Following historical experience concerning the development of the firepower-mobility trade-off (Dinter, 1985: 55ff.) we expect a general combat environment more favorable for the defender in the periods between 1850 and 1930. Especially during this period, firepower (breech-loading and magazine rifles and artillery, machine guns, heavy artillery, smokeless powder etc.) clearly grew faster than mobility (still basically dependent on the marching abilities of the soldiers on the ground, or on horses), firepower tended to pin forces down without giving 
them the opportunities to pass or circumvent the killing zones. This point is supported by the general rule that flank attacks are more likely to succeed than frontal attacks (Dupuy, 1990: 327ff.). Correspondingly, there should be a general negative impact of the defender's posture on the likelihood of an attacker's victory. Notwithstanding historical examples of turning maneuvers, prepared or fortified defensive positions should at least delay an attack, and at best enable the defender to defeat the attacker (Dupuy, 1990: 329f.). Finally, based on Clausewitz' (1990: 173ff.), we expect a persistently positive effect of surprise on the chances to win a battle. For the quantitative findings of the QJM and TNDM, Dupuy (1990: 332) has hinted at the fact that the achievement of tactical surprise results in a substantial enhancement of combat power.

\section{Empirical methodology and specifications}

\section{The statistical model}

Since our principal dependent variable, Victory, is dichotomous, our empirical investigation builds on a standard binary choice model, the Probit model as explained by Amemiya (1981) or Maddala (1983). Based on a vector of explanatory variables $x$ for each observation, the probability of an attacker's success or failure in battle $j$ is given by

$$
\text { Prob. }\left(\text { Victory }_{j}=1\right)=F\left(\beta x_{j}\right),
$$

and, correspondingly,

$$
\text { Prob. }\left(\text { Victory }_{j}=0\right)=1-F\left(\beta^{\prime} x_{j}\right) \text {. }
$$

In order to avoid nonsense probabilities, i.e. to restrict the outcomes of the model to the $[0,1]$ interval, a distribution $\mathrm{F}$ is chosen which secures that, for a given regressor vector,

$$
\lim _{\beta^{\prime} x \rightarrow \infty} \text { Prob. }(\text { Victory }=1)=1
$$

and

$$
\lim _{\beta^{\prime} x \rightarrow-\infty} \text { Prob. }(\text { Victory }=1)=0 .
$$

In case of the Probit model the standard normal distribution $\Phi$ is chosen, giving us the probability of battle success as

$$
\text { Prob. }\left(\text { Victory }_{j}=1\right)=\Phi\left(\beta^{\prime} x_{j}\right) .
$$

The coefficient vector $\beta$ is estimated by a standard maximum likelihood procedure. One should note that the Probit model represents a nonlinear framework of estimation. Coefficients are larger in magnitude than the corresponding marginal effects on the probability of achieving victory, that is larger than the change in the success probability when the explanatory factor is 
increasing slightly. The corresponding factor of proportionality varies with the probability of success. That is, in situations in which victory is very likely, a small change in, say, the force ratio, exerts only a relatively small marginal effect on the likelihood of winning. In the presentation of statistical models of discrete choice, it is therefore necessary to calculate and document marginal effects, together with an indication of the specific situation for which they are derived. Furthermore, variable transformations like (force ratio) ${ }^{2}$ add another element of nonlinearity to the analysis. Specifically, the marginal effect of an increase in the force ratio differs across battles systematically as a function of the actual force ratio characterizing the combat situation.

The empirical analysis is done in three basic steps. In the first step, we (1) estimate a Probit model for victory, pooling the data for the whole period of 1600 to 1973, using the variables on the relative quantitative and qualitative positions of the offensive and the defensive side. In the second step, we (2) allow the coefficients on the substantive variables to vary over time according to a linear trend. Finally, the third step entails (3) splitting the sample and performing a separate analysis for the three sub-periods 1600-1849, 1850-1929, and 1930-1973. In all specifications, intertemporal differences in the relative position of the attacker are captured by allowing intercepts to differ across these three sub-periods. Note that this implies the role of changing technology to be covered in two distinct ways. First, technology measures the relative technological superiority (or inferiority) of the attacking side within the contemporary framework of battle. Second, our variables for the progress of time indirectly cover the intertemporal dynamics of military technology.

\section{Estimation results}

This section provides a comprehensive overview of the empirical determinants of battle success from the 17th century until the period preceding more or less current developments in military technology. First, we document the general pattern regarding the impact of various aspects of battle success. Then we exemplify our quantitative results using several important historical battles, before we, finally, address the issue of intertemporal changes in the role of success factors. 


\section{The general pattern}

Our first set of results attempts to tie down the impact that various potential determinants have exerted, over the historical period considered, on the battlefield success of an attacker. That is, we pool our data and restrict the impact of the quantitative and qualitative determinants documented in Table 1 and discussed in section 4 to be the same throughout all periods considered. The focus of our presentation lies on marginal effects of the factors considered, that is the change in the likelihood of winning as a response to a slight change in the value of the factor, holding all other factors constant at the sample mean. For purposes of reference, the estimated marginal effects of our preferred specification - allowing for a nonlinear effect of the force ratio on success - are compared in Table 2 to a specification restricting this effect to be linear.

These estimation results consistently confirm a positive impact of numerical superiority on battlefield success. According to our preferred specification (column 2), at the typical situation of approximately double the strength of forces (216.4 percent), adding to the attacker's forces another 10 percent of personnel (i.e. increasing the force ratio by 0.2164 ) increases the likelihood of winning by approximately two percentage points $(0.2164 \cdot 0.0953=0.021)$. The estimated marginal effect of an increasing force ratio decreases with its level, though. For instance, in a battle situation with a force ratio of $(2 \cdot 2.164=) 4.328$, the corresponding effect of adding another 5 percent of personnel (also increasing the force ratio by 0.2164 ) is estimated to increase the likelihood of success by merely 1.5 percentage points $(0.2164 \cdot 0.0678=0.015)$. Note that this second estimate of the marginal effect is not significantly different from zero, due to the increasing (with a rising force ratio) importance of the negative coefficient of (force ratio $)^{2}$ which has been estimated less precisely than the linear effect.

When the effect of the force ratio is restricted to be linear (column 1), the marginal effect of a corresponding increase of the force ratio by 0.2164 is estimated to be only slightly higher than one percentage point $(0.2164 \cdot 0.0516=0.012)$, irrespective of the level of the force ratio at which this hypothetical increase is considered. That is, in a linear specification the relatively low marginal effect of an increasing numerical superiority at high levels of the force ratio (recall that in the data the variable force ratio takes values almost up to 17) is reflected in a small overall estimate. By contrast, the quadratic specification allows the estimates to reflect both a strong impact of rising numerical strength at low levels of the force ratio and a weak 
impact when numerical superiority is already considerable. Also, the predictive power of our estimations is considerable, and slightly higher when (force ratio $)^{2}$ is included. Therefore, the quadratic specification documented in column 2 of Table 2 is our preferred specification.

Inspection of the marginal effects of the other success factors reveals that the decision between inclusion or exclusion of the quadratic term (force ratio $)^{2}$ is completely inconsequential for our conclusions regarding these qualitative determinants. Note that the appropriate marginal effect of indicator (1/0) variables is not the change in the likelihood of winning the battle as a response to a slight change in the determinant (since it can only take on the values 0 or 1 ), as for the continuous variable force ratio. Rather, the appropriate figure is the change in the success probability as the indicator variable is set from 0 to 1 , holding all other variables constant at their sample mean. No major discrepancies arise in a comparison of the marginal effects across the two columns of Table 2.

While the estimated marginal impact of a defensive posture favoring the defender is estimated to be negative, this estimate is not significant, indicating that this factor did not play a major role for the battles represented in our data. By contrast, surprise seems to be an important element of battle success, with a marginal effect of almost 15 percentage points. Of the qualitative human elements of combat included in our specifications, leadership seems to be the crucial factor. Its estimated marginal effect is nearly one half, indicating that, everything else held constant, superior leadership is instrumental for success in the battlefield. Similarly important, albeit at a smaller numerical magnitude of approximately 25 percentage points is morale. On the other hand, superior training did not exert any significant impact on battlefield success throughout the period. Finally, two of the qualitative variables assessing an attacker's technological advantage, logistics (marginal effect approximately 20 percent) and intelligence (slightly more than 25 percent) seem to be instrumental for battlefield success. Unsurprisingly, given the low number of cases in which there has been any advantage for the attacker in this dimension, technology is estimated to be a negligible factor.

\section{Two exemplary simulations}

In order to explore the actual quality of our estimations for predicting concrete battle outcomes, we look at simulation results for two famous battles, Waterloo (in June 1815) and Gettysburg (in July 1863). At Waterloo, Napoleon I., with about 68,000 men, faced a combined Anglo- 
Prussian force of about 137,000 commanded by the Duke of Wellington and Marshal Blücher, with the latter coming to support the former (Dupuy, 1995: 115). The British were positioned on a ridge with several fortified farms providing additional cover, giving us a Posture of 1.

The French intelligence underestimated the Prussians " remaining fighting abilities after their defeat at Ligny two days earlier as well as their resolution to assist Wellington in his defense against Napoleon's attacks in the afternoon of 18 June 1815, which results in Intelligence $=0$. Napoleon was seriously surprised by the stubborn British resistance and by the Prussians' fast appearance on the battlefield (Surprise $=0$ ), which finally decided the combat in favor of the Allies. With no other significant differences in the opponents' quality factors, these data result in $\beta^{\prime} x=-0.896$ according to our Probit estimations, giving Napoleon a chance of winning at Waterloo of 18 percent.

This result is in stark contrast to contemporary assessments (Holmes, 1976: 56ff.; Keegan, 1981: 135ff.). Our simulation shows that Wellington's famous statement that the battle had been a very "close thing" was somewhat exaggerated, just as Napoleon's hope that his chances were still 60 to 40 after the arrival of the Prussians was overoptimistic. This also holds if one changes the setting by ignoring the Prussians' actual impact and looking at the result for Napoleon facing only Wellington's army of 66,000. This would have been the case if Grouchy had fulfilled his task of harassing the Prussian army effectively. With everything else held constant, the odds against the French improve only slightly, i.e. to 26 percent.

Another famous, somewhat self-assured citation by Wellington, however, can be verified by our results. According to the British commander, it would not have worked for the Allies if he himself had not been on the ground, and this seems true if one changes Napoleon's relative superiority in Leadership from 0 to 1 , a value that our data set attributes to his position at Austerlitz in 1805. Without the "Wellington effect" neutralizing Napoleon's military genius (apart from the Emperor's age and illness), such a leadership advantage would have given rise to the probability of a French victory (ceteris paribus) of 79 percent.

Another set of simulations that we offer is for the three-day battle of Gettysburg between the attacking Confederate army of 75,000 under General Robert E. Lee against the Union forces of 83,000 commanded by General George C. Meade. Neither side possessed a significant advantage according to our quality factors, except for a slight disadvantage in Intelligence $(=0)$ 
for the Confederates. Simulations based on the estimation results of Table 2 give us a probability of a Southern victory of 20 percent.

Given the failure of the famous "Pickett's charge" on 3 July 1863, the third day of the battle (Holmes, 1976: 109ff.), one might ask whether the result would have been different if Lee's army had been of equal numerical strength to the Union forces. Simulating such a situation, however, only results in a slight improvement of the Confederates' chances by one percentage point, no more. Again, a different picture evolves if one assumes a leadership advantage for Lee similar to the first two years of the Civil War, when our data frequently ascribe a Leadership value of 1 to the Confederates. Given such an advantage, the probability of a Southern victory at Gettysburg increases to 81 percent.

In addition to their usefulness as an unemotional instrument for the systematic analysis of historical battles, these simulations also illustrate the sensitivity of the analysis to the ex-post assessments of the qualitative aspects of combat, such as leadership and morale. While the plausibility of our substantive results is comforting, our major focus is on the quantitative determinant force ratio. That, on balance, this factor for battlefield success is important has been demonstrated here. What remains to be investigated is whether this instrumental role is retained as military technology evolves over time.

\section{Intertemporal analysis}

We pursue two specifications to assess the variability of our substantive results over time. One strategy is to allow the effects of all determinants of battle success to increase or decrease systematically according to a linear time trend. That is, in addition to the regressors whose marginal effects are documented in column 2 of Table 2, and in addition to the constant term and the two period-specific indicators which are already present in this baseline specification, we include as additional regressors interaction terms between the determinants themselves and a linear trend term $\left(x_{j} \cdot t\right)$. The corresponding marginal effects are therefore specified to vary systematically over time as well.

Note that for most of the qualitative variables, neither this generalization of the baseline specification nor the one discussed below altered our qualitative conclusions. Somewhat remarkable exceptions are leadership and training which were apparently particularly important during the first era (1600-1849). We do not place too much emphasis on this apparent change, 
however, for two reasons. First, leadership is estimated to retain an important role also in more recent periods, just with a lower magnitude. Second, the estimated importance particularly of leadership during this early era might at least partially reflect the dearth of precise quantitative information in the construction of historical battle data.

Consequently, our intertemporal analysis focuses on the marginal effect of numerical superiority, holding constant all variables at their respective means over the pooled sample. In particular, the value of the variable force ratio is held constant at 2.164 throughout these calculations. The intertemporal structure of the corresponding marginal effects is documented in Table 3. In our baseline specification of Table 2, the marginal effect was restricted to be constant throughout the sampling period. This effect is reported for purposes of reference in the first row of the Table. In the second row, the marginal effect ist reported for the years 1725 , 1890, and 1960, respectively, each representing one of the three eras 1600-1849, 1850-1929, and 1930-1973.

Clearly, the marginal effect of numerical superiority, that is the change in the likelihood of battle success when the force ratio is increased slightly to the favor of the attacker, is estimated to be decreasing over time, from 0.1437 in 1725 to a mere 0.0671 in 1960 . Together with the general tendency towards higher force ratios which apparently feeds into a nonlinear effect of this variable on the likelihood of success, it seems clear that numerical superiority has not been of the same importance in more recent battles than in the distant past.

Yet, our second extended specification uncovers this interpretation as too narrow. Specifically, in this specification we allow the effects of all determinants to differ nonparametrically across the three principal eras 1600-1849, 1850-1929, and 1930-1973, respectively. The third row of Table 3 documents that the marginal effect of an increasing force ratio is estimated as particularly low for the era 1850-1929, the period for which we had generally predicted attackers' chances to be atypically low. Yet, while the marginal effect of increasing numerical superiority is not estimated exactly as high for the third era, 1930-1973, as for the first, its estimate is nevertheless almost as high.

The linear trend-in-coefficients- specification of row 2 cannot capture this pattern. To the contrary, given the strong dip during the intermediate era and the less than complete recovery of the marginal effect, it is restricted to suggest a continuing downward trend by construction. In conclusion, our estimates indicate clearly that in addition to the apparent 
temporal stability of the importance of qualitative factors of battle success, and despite some fluctuations over time, numerical superiority has been a crucial quantitative determinant of battlefield success throughout history. Specifically, it has not lost its importance for the likelihood of successful attack in the most recent historical experiences available for analysis.

\section{Conclusions}

Two fundamental results of our empirical analysis are most striking vis-à-vis the role of technology in modern warfare. First, and most important, we find no evidence that technological superiority has ever achieved the status of a factor that is exclusively responsible for winning battles during the almost four centuries of warfare we have analyzed here. Second, at least since the 19th century, it has become increasingly difficult to find a parsimonious empirical structure capturing the effect of technological change on warfare. Actually, this empirical watershed coincides in principle with van Creveld's (1989: 153ff.) change from the "age of machines" to the "age of systems", at least if one interprets the wars of the late 19th century as preludes in a transition period towards systemic warfare (O'Connell, 1989: 231ff.).

In general, our findings seem to confirm Dupuy‘s (1987: 214/218) observation that technology "can upset, restore, or perpetuate a combat power balance or imbalance. But the advantage is fleeting, rarely decisive, and never as decisive as promised or expected. (...) up until the present no conventional weapon has been as important to battle success as have been the troops employing the weapons." Indeed, our results suggest that, apart from superior numbers, intelligence and logistical advantages, it was the quality of commanders and men which was decisive for the outcome of battles throughout modern history. Empirically essential factors of the production of victory were superior leadership qualities, surprise of the enemy, and better morale, i.e. doctrine, professionalism and organization.

The consequences of these partly surprising empirical results are not only interesting from a historical perspective but also relevant for the current discussion about the "revolution in military affairs“ (e.g. Blank, 1996; Hermann, 1996; Libicki, 1996; Ritcheson, 1996; Arquilla and Karmel, 1997; Metz, 1997; Owens, 1998) which is seen as a consequence of a militarytechnological "information revolution" (Gupta, 1995; Cohen, 1996; Davis, 1996). As a consequence of the perceived RMA and the global US leadership in its driving technologies, the four operational concepts of the US "Joint Vision 2010" (CJCS, 1998) have been building on 
new (including non-lethal) weaponry based on direct energy, stealth technology and information superiority, culminating in a "system of systems".

If technology and training are not found to be empirically significant elements of success on the tactical and operational level, however, military history contradicts the emphasis on these factors which can be found extensively in the literature on modern warfare. Since at the same time, our analysis suggests that traditional human elements of success, like leadership, surprise and morale, remain clearly more essential than technology, it supports the more skeptical views of the RMA stressing the non-mechanistic, organic aspects of modern combat. According to our results, success in combat can be achieved without technological sophistication if only systemic efficiency and optimal interaction of the various arms and levels of modern armed forces are obtained. Effective military action on the ground apparently depends mainly on the organizational quality of forces and their doctrine, not on high-tech weaponry. Only via intelligence or surprise might there be a substantial indirect effect of current modern technology.

Theoretical explanations for our empirical findings might be found in Biddle's (1996a, 199b, 1997) and Press' (1997) arguments about the decisive role of the synergy between the effects of modern technology and the adversary's mistakes, or in the civil-military relations nexus resulting in effective use of high-tech weaponry and in the military's ability actually to use it in areas of intervention in civilian affairs. In both cases, technological advantage (including technical knowledge about operating the modern systems by better training) will not per se be decisive for combat success. Only through superior leadership and efficient overall organization will the technologically superior side be able to exploit the opponent's tactical errors or use the better technology effectively. Efficient organization also incorporates doctrine, military philosophy and "culture", i.e. it is closely connected to societal norms and basic political attitudes and decisions.

Biddle's arguments could explain the reported insignificance of technological superiority in war: basically, it seems to be an army's character and organization, i.e. its "software", which win battles, not the hardware available. If software is thus more essential in combat than hardware, it will be able to substitute for technological shortcomings, at least to a certain degree. Thus, despite several methodological weaknesses caused by the data situation, this paper supports some serious doubts (discussed by Blank, 1996; Cohen, 1996; Herman, 1996; Libicki, 1996; Arquilla and Karmel, 1997) about the technology-fixated view of many military and 
politico-economic analysts concerning the "revolution in military affairs" and the evolution of modern warfare.

One has finally to state that our results have still to be taken with a grain of salt. This does not depend on the problems of data construction or model assumptions discussed above. In a more fundamental sense, the main weakness of our data concerns the lack of information about battles avoided by inferior opponents. Our data are likely to be shaped by the problem of a selection bias given in virtually all historical data of this kind. Moreover, basic doubts may remain, concerning the possibility to draw conclusions from historical developments, even previous "RMAs", for "unique" current conditions. Technically, this represents the problem of out-of-sample predictions. Nevertheless, despite all remaining methodological problems which obviously necessitate further research, our empirical results are certainly sufficient to support doubts about some current popular arguments concerning the changing factors of effectiveness in military combat, and their consequences for defense economics and policies. 


\section{References}

Amemiya, T.: (1981) Qualitative response models: A survey. Journal of Economic Literature, 19 (4), 483-536.

Andrews, Marshall: (1977) The Germans create the combat team. History, Numbers, and War, $1(1), 13-16$.

Arquilla, John and Karmel, Solomon M.: (1997) Welcome to the revolution... in Chinese military affairs. Defense Analysis, 13 (3), 255-270.

Bacevich, A. J.: (1997) Tradition abandoned: America's military in a new era. The National Interest, 48, 16-25.

Bauer, Thomas and Rotte, Ralph: (1997) Prospect theory goes to war: Loss-aversion and the duration of military combat. University of Munich, SFB 386 Discussion Paper 97.

Biddle. Stephen: (1996a) Victory misunderstood. What the Gulf War tells us about the future of conflict. International Security, 21 (2), 139-179.

Biddle, Stephen: (1996b) Technology, civil-military relations, and warfare in the developing world. Journal of Strategic Studies, 19 (2): 171-212.

Biddle, Stephen: (1997) The Gulf War redux: Why skill and technology are the right answer. International Security, 22 (2): 163-174.

Black, Jeremy: (1997) The Military Revolution II: Eighteenth-century war. In: Charles Townshend (ed.), The Oxford illustrated history of modern war, Oxford: Oxford University Press, 35-63.

Blaker, James R.: (1997) The American RMA force: An alternative to the QDR. Strategic Review, 25 (3), 21-30.

Blank, Stephen J.: (1996) Preparing for the next war: Reflections on the Revolution in Military Affairs. Strategic Review, 24 (2), 17-25.

de Bloch, Jean: (1901) The wars of the future. Contemporary Review, 80: 305-332.

Bourne, John: (1997) Total war I: The Great War. In: Charles Townshend (ed.), The Oxford illustrated history of modern war, Oxford: Oxford University Press, 100-119.

Chairman of Joint Chiefs of Staff (CJCS): (1998) Joint vision 2010. America's military preparing for tomorrow. Washington, D.C.

Childs, John: (1997) The Military Revolution I: The transition to modern warfare. In: Charles Townshend (ed.), The Oxford illustrated history of modern war, Oxford: Oxford University Press, 19-34. 
von Clausewitz, Carl: (1990) Vom Kriege. Augsburg: Weltbild.

Cohen, Eliot A.: (1996) A revolution in warfare. Foreign Affairs, 75 (2), 37-54.

Cohen, William S.: (1997) Report of the Quadrennial Defense Review, May 1997. http://www.defenselink.mil/pubs/qdr, July 1998.

van Creveld, Martin: (1989) Technology and war: From 2000 B.C. to the present. New York: Free Press.

van Creveld, Martin: (1997a) Technology and war I: to 1945. In: Charles Townshend (ed.), The Oxford illustrated history of modern war, Oxford: Oxford University Press, 175-193.

van Creveld, Martin: (1997b) Technology and war II: Postmodern war? In: Charles Townshend (ed.), The Oxford illustrated history of modern war, Oxford: Oxford University Press, 298-314.

Davis, Norman C.: (1996) An information-based Revolution in Military Affairs. Strategic Review, 24 (1), 43-53.

Dinter, Elmar: (1985) Nie wieder Verdun. Überlegungen zum Kriegsbild der 90er Jahre. Herford: Mittler \& Sohn.

Dupuy, R. Ernest and Dupuy, Trevor N.: (1993) The Harper encyclopedia of military history. From 3500 B.C. to the present. New York: Harper Collins Publishers (4th edition).

Dupuy, Trevor N.: (1979) Numbers, Predictions, and War. Fairfax, VA: Hero Books.

Dupuy, Trevor N.: (1987) Understanding War. History and the Theory of Combat. New York: Paragon House.

Dupuy, Trevor N.: (1990) The evolution of weapons and warfare. New York: Da Capo Press.

Dupuy, Trevor N.: (1995) Attrition: Forecasting battle casualties and equipment losses in modern war. Falls Church, VA: Nova Publications.

Forrest, Alan: (1997) The nation in arms I: The French wars. In: Charles Townshend (ed.), The Oxford illustrated history of modern war, Oxford: Oxford University Press, 48-63.

French, David: (1997) The nation in arms II: The nineteenth century. In: Charles Townshend (ed.), The Oxford illustrated history of modern war, Oxford: Oxford University Press, 64-80.

Frese, Michael and Zapf, Dieter: (1987) Die Einführung von neuen Technologien verändert Qualifikationsanforderungen, Handlungsspielraum und Stressoren kaum. Zeitschrift für Arbeitswissenschaft, 41 (1), 7-14.

Ginsberg, Daniel: (1998) Transformational change and the future of the Chinese military. SAIS Review, 18 (1), 153-174. 
Gupta, Vipin: (1995) New satellite images for sale. International Security, 20 (1), 94-125.

Hacker, Barton C.: (1994) Military institutions, weapons, and social change: Toward a new history of military technology. Technology and Culture, 35 (4), 768-834.

Headrick, Daniel: (1981) The tools of empire: Technology and European imperialism in the nineteenth century. Oxford: Oxford University Press.

Helmbold, Robert L.: (1991) Combat effectiveness data set, prepared by the US Army Concepts Analysis Agency, Bethesda, MD. Available via internet from A. C. Stam, http://www.yale.edu/plsc151a.

Helmbold, Robert L.: (1997) The advantage parameter: A compilation of Phalanx articles dealing with the motivation and empirical data supporting the use of the advantage parameter as a general measure of combat power. Bethesda, MD: US Army Concepts Analysis Agency.

Herman, Paul F.: (1996) The revolution in "military" affairs. Strategic Review, 24 (2), 26-30.

Holmes, Richard: (1976) Landschlachten der Weltgeschichte. Hamburg: Periscope Verlag.

Howard, Michael: (1976) War in European history. Oxford: Oxford University Press.

Keegan, John: (1981) Die Schlacht. Azincourt 1415 - Waterloo 1815 - Somme 1916. Munich: Deutscher Taschenbuch Verlag.

Keegan, John: (1994) A history of warfare. London: Randomhouse.

Lanchester, Frederick W.: (1977) The principle of concentration. Reprinted in: History, Numbers, and War, 1 (3), 142-146.

Libicki, Martin: (1996) The emerging primacy of information. Orbis, 40 (2), 261-276.

Lynn, John A.: (1995a) States in conflicts 1661-1763. In: Geoffrey Parker (ed.), The Cambridge illustrated history of warfare. The triumph of the West, London: BCA, 164-185.

Lynn, John A.: (1995b) Nations in arms 1763-1815. In: Geoffrey Parker (ed.), The Cambridge illustrated history of warfare. The triumph of the West, London: BCA, 186-213.

Maddala, G.S.: (1983) Limited-dependent and qualitative variables in econometrics. Cambridge: Cambridge University Press.

McNeill, William H.: (1982) The pursuit of power: Technology, armed force and society since A.D. 1000. Chicago: University of Chicago Press.

Messenger, Charles: (1995) The century of warfare. Worldwide conflict from 1900 to the present day. London: Harper Collins Publishers. 
Metz, Steven: (1997) Racing toward the future: The Revolution in Military Affairs. Current History, 96 (609), 184-188.

Montgomery, Bernard: (1968) A history of warfare. London: Wm. Collins Sons \& Co.

Murray, Williamson A.: (1995a) The industrialization of war 1815-71. In: Geoffrey Parker (ed.), The Cambridge illustrated history of warfare. The triumph of the West, London: BCA, 216-241.

Murray, Williamson A.: (1995b) Towards world war 1871-1914. In: Geoffrey Parker (ed.), The Cambridge illustrated history of warfare. The triumph of the West, London: BCA, 242-265.

Murray, Williamson A.: (1995c) The West at war 1914-18. In: Geoffrey Parker (ed.), The Cambridge illustrated history of warfare. The triumph of the West, London: BCA, 266-297.

Murray, Williamson A.: (1995d) The world in conflict 1919-41. In: Geoffrey Parker (ed.), The Cambridge illustrated history of warfare. The triumph of the West, London: BCA, 298-319.

Murray, Williamson A.: (1995e) The world at war 1941-45. In: Geoffrey Parker (ed.), The Cambridge illustrated history of warfare. The triumph of the West, London: BCA, 320-339.

Murray, Williamson A.: (1995f) The post-war world 1945-95. In: Geoffrey Parker (ed.), The Cambridge illustrated history of warfare. The triumph of the West, London: BCA, 340-363.

O'Connell, Robert: (1989) Of arms and men: A history of war, weapons, and aggression. Oxford: Oxford University Press.

Owens, Mackubin T.: (1998) Technology, the RMA, and future war. Strategic Review, 26 (2), 63-70.

Overy, Richard: (1997) Total war II: The Second World War. In: Charles Townshend (ed.), The Oxford illustrated history of modern war, Oxford: Oxford University Press, 120-137.

Parker, Geoffrey: (1988) The military revolution: Military innovation and the rise of the West, 1500-1800. Cambridge: Cambridge University Press.

Parker, Geoffrey: (1995a) The western way of war. In: Geoffrey Parker (ed.), The Cambridge illustrated history of warfare. The triumph of the West, London: BCA, 2-9.

Parker, Geoffrey: (1995b) Dynastic war 1494-1660. In: Geoffrey Parker (ed.), The Cambridge illustrated history of warfare. The triumph of the West, London: BCA, 146-163.

Parker, Geoffrey: (1995c) The future of western warfare. In: Geoffrey Parker (ed.), The Cambridge illustrated history of warfare. The triumph of the West, London: BCA, 364-373.

Press, Daryl G.: (1997) Lessons from ground combat in the Gulf: The impact of training and technology. International Security, 22 (2), 137-146. 
Reiter, Dan and Stam, Allan C.: (1998) Democracy and battlefield military effectiveness: Democracy, war initiation, and victory. Journal of Conflict Resolution, 92 (2): 377-389.

Ritcheson, Phillip L.: (1996) The future of "military affairs": Revolution or evolution? Strategic Review, 24 (2), 31-40.

Stam, Allan C.: (1996) Win, lose or draw. Domestic politics and the crucible of war. Ann Arbor: University of Michigan Press.

Stegemann, Hermann: (1940) Der Krieg. Sein Wesen und seine Wandlung, vol.2. Stuttgart, Berlin: Deutsche Verlagsanstalt.

Storz, Dieter: (1992) Kriegsbild und Rüstung vor 1914. Europäische Landstreitkräfte vor dem Ersten Weltkrieg. Herford: Mittler \& Sohn.

Towle, Philip: (1997) Cold War. In: Charles Townshend (ed.), The Oxford illustrated history of modern war, Oxford: Oxford University Press, 138-154.

Townshend, Charles: (1997) The shape of modern war. In: Charles Townshend (ed.), The Oxford illustrated history of modern war, Oxford: Oxford University Press, 3-18.

Veall, Michael R. and Zimmermann, Klaus F.: (1996) Pseudo-R ${ }^{2}$ measures for some common limited dependent variable models. Journal of Economic Surveys, 10 (3), 241-259.

Wilson, Andrew: (1984) Das Abrüstungshandbuch. Analysen, Zusammenhänge, Hintergründe. Hamburg: Hoffmann und Campe. 
Table 1: Variables and descriptive statistics

\begin{tabular}{|c|c|c|c|}
\hline Variable & Description & Mean & Std.dev. \\
\hline Victory & $\begin{array}{l}\text { Indicator }(1 / 0) \text { variable for the outcome } \\
\text { of the engagement or battle: } \\
0 \text { (attacker loses or draw) } \\
1 \text { (attacker wins) }\end{array}$ & 0.5968 & 0.491 \\
\hline Force ratio & $\begin{array}{l}\text { Attacker's total personnel strength } \\
\text { divided by defender's total personnel } \\
\text { strength }\end{array}$ & 2.1641 & 2.104 \\
\hline Posture & $\begin{array}{l}\text { Indicator (1/0) variable for the character } \\
\text { of the defender's position: } \\
0 \text { (at most one defensive posture) } \\
1 \text { (two separate or distinct defensive } \\
\text { postures - or - an intermixture of two or } \\
\text { more defensive postures) }\end{array}$ & 0.1984 & 0.399 \\
\hline Surprise & $\begin{array}{l}\text { Indicator }(1 / 0) \text { variable for the relative } \\
\text { effective surprise achieved by the } \\
\text { attacker: } \\
0 \text { (no surprise) } \\
1 \text { (surprise) }\end{array}$ & 0.2704 & 0.445 \\
\hline Leadership & Indicator $(1 / 0)$ variables for attacker's & 0.2688 & 0.444 \\
\hline Training & $\begin{array}{l}\text { relative advantage in leadership, } \\
\text { training, morale etc.: }\end{array}$ & 0.1776 & 0.382 \\
\hline Morale & $\begin{array}{l}0 \text { (no advantage }) \\
1 \text { (with advantage })\end{array}$ & 0.2112 & 0.408 \\
\hline Logistics & & 0.0848 & 0.279 \\
\hline Intelligence & & 0.1280 & 0.334 \\
\hline Technology & & 0.0416 & 0.200 \\
\hline
\end{tabular}

625 observations. 
Table 2: The determinants of attacker's battle success - a Probit model, 1600-1973

\begin{tabular}{|c|c|c|}
\hline Marginal effects & linear in force ratio & quadratic in force ratio \\
\hline $\begin{array}{l}\text { Force ratio } \\
\text { (at the sample mean: } 2.164 \text { ) }\end{array}$ & $\begin{array}{l}0.0516^{* *} \\
\quad(4.01)\end{array}$ & $\begin{array}{l}0.0953 * * \\
\quad(2.42)\end{array}$ \\
\hline $\begin{array}{l}\text { Force ratio } \\
\text { (at double the sample mean: } 4.328 \text { ) }\end{array}$ & $\begin{array}{l}0.0516^{* *} \\
\quad(4.01)\end{array}$ & $\begin{array}{c}0.0678 \\
(1.38)\end{array}$ \\
\hline Posture $^{1}$ & $\begin{array}{c}-0.0153 \\
(0.28)\end{array}$ & $\begin{array}{c}-0.0255 \\
(0.46)\end{array}$ \\
\hline Surprise $^{1}$ & $\begin{array}{l}0.1423 * * \\
(2.76)\end{array}$ & $\begin{array}{l}0.1412 * * \\
\quad(2.72)\end{array}$ \\
\hline Leadership $^{1}$ & $\begin{array}{l}0.4530^{* *} \\
\quad(9.17)\end{array}$ & $\begin{array}{l}0.4630^{* *} \\
(9.32)\end{array}$ \\
\hline Training $^{1}$ & $\begin{array}{c}-0.0181 \\
(0.27)\end{array}$ & $\begin{array}{c}0.0046 \\
(0.07)\end{array}$ \\
\hline Morale $^{1}$ & $\begin{array}{l}0.2683 * * \\
(5.23)\end{array}$ & $\begin{array}{l}0.2607 * * \\
(5.02)\end{array}$ \\
\hline Logistics $^{1}$ & $\begin{array}{l}0.2019 * * \\
(2.53)\end{array}$ & $\begin{array}{l}0.1996 * * \\
(2.49)\end{array}$ \\
\hline Intelligence $^{1}$ & $\begin{array}{l}0.2585^{* *} \\
(3.39)\end{array}$ & $\begin{array}{l}0.2584 * * \\
\quad(3.36)\end{array}$ \\
\hline Technology ${ }^{1}$ & $\begin{array}{c}-0.0616 \\
(0.53)\end{array}$ & $\begin{array}{c}-0.0852 \\
(0.72)\end{array}$ \\
\hline Pseudo-R ${ }^{2}$ & 0.2808 & 0.2891 \\
\hline \multicolumn{3}{|c|}{$\begin{array}{l}625 \text { observations; absolute t-values are reported in parentheses; the "**" and the "** indicate } \\
\text { statistical significance at the } 5 \text { percent level and the } 10 \text { percent level, respectively; the }{ }^{1} \text { indicates } \\
\text { that the marginal effect for the corresponding indicator }(1 / 0) \text { variable is calculated as a } \\
\text { difference in predicted probabilities for the change from } 0 \text { to } 1 \text {; the Probit specifications also } \\
\text { allow for an intercept and two period indicators for } 1850-1929 \text { and } 1930-1973 \text {, respectively. }\end{array}$} \\
\hline
\end{tabular}


Table 3: The marginal effect of an increasing force ratio - changes over time, 1600-1973

\begin{tabular}{lcccc}
\hline \hline & $1600-1849$ & $1850-1929$ & $1930-1973$ & Pseudo-R $^{2}$ \\
\hline $\begin{array}{l}\text { Baseline model } \\
\text { (Table 2, column 2) }\end{array}$ & 0.0953 & 0.0953 & 0.0953 & 0.2891 \\
$\begin{array}{l}\text { A linear trend in the effect } \\
\text { of determinants }\end{array}$ & 0.1437 & 0.0899 & 0.0671 & 0.3117 \\
$\begin{array}{l}\text { Effects of determinants } \\
\text { differ across sub-periods }\end{array}$ & 0.1277 & 0.0322 & 0.1029 & 0.3367 \\
\hline
\end{tabular}

Evaluation of marginal effects is at the sample mean for all variables, and allows for a quadratic effect in the force ratio. ${ }^{1}$ The marginal effect in the linear-trend model has been evaluated for 1725,1890 , and 1960, respectively. 


\section{IZA Discussion Papers}

$\begin{array}{ll}\text { No. } & \text { Author(s) } \\ 474 & \begin{array}{l}\text { J. T. Addison } \\ \text { L. Bellmann } \\ \text { A. Kölling }\end{array} \\ 475 & \begin{array}{l}\text { Z. Hercowitz } \\ \text { E. Yashiv }\end{array} \\ 476 & \begin{array}{l}\text { W. A. Cornelius } \\ \text { T. Tsuda }\end{array}\end{array}$

$477 \quad$ M. A. Clark

D. A. Jaeger

478

479

J. H. Bishop

L. Woessmann
A. L. Booth

M. L. Bryan

R. L. Lumsdaine

E. S. Prasad
A. Ciccone
G. Peri

D. Del Boca

S. Pasqua

R. Rotte

C. M. Schmidt
Title

Area

Date

Unions, Works Councils and Plant Closings in

3

04/02

Germany

A Macroeconomic Experiment in Mass

1

04/02

Immigration

Labor Market Incorporation of Immigrants in Japan and the United States: A Comparative Analysis

Natives, the Foreign-Born and High School

Equivalents: New Evidence on the Returns to the GED

Uneven Technical Progress and Unemployment

04/02

Unions and Employment Growth: The One

04/02

Constant?

The Complexity of Economic Policy:

I. Restricted Local Optima in Tax Policy Design

Hiring Standards and Market Clearing

$04 / 02$

Leadership Skills and Wages

04/02

In-Group Cooperation in a Hostile Environment:

An Economic Perspective on Some Aspects of Jewish Life in (Pre-Modern) Diaspora

Institutional Effects in a Simple Model of

Educational Production

5

04/02

Class-Size Effects in School Systems Around the World: Evidence from Between-Grade Variation in TIMSS

Who pays for General Training? New Evidence for British Men and Women

Identifying the Common Component of International Economic Fluctuations:

A New Approach

Identifying Human Capital Externalities:

Theory with an Application to US Cities

Employment Patterns of Husbands and Wives and Family Income Distribution in Italy (19771998)

Social Security and Taxation of Labour Subject to Subsidiarity and Freedom of Movement

On the Production of Victory: Empirical Determinants of Battlefield Success in Modern War 